\title{
Medication consumption in a Brazilian area covered by the Family Health Strategy: Prevalence and associated factors
}

\author{
Consumo de medicamentos na área de abrangência de uma Estratégia de Saúde da Família: \\ Prevalência e fatores associados
}

Consumo de medicamentos en el área de alcance de una Estrategia de Salud de la Familia: Prevalencia y factores associados

Letícia Silveira Goulart ${ }^{1}$ [ Ingrid Jordana Ribeiro Dourado ${ }^{1}$ (iD Alyna Araújo e Marcondes ${ }^{1}$ (id Aline Marques ${ }^{1}$ (i) Franciane Rocha de Faria ${ }^{1}$ (i) Débora Aparecida da Silva Santos ${ }^{1}$ (D)

1. Universidade Federal de Rondonópolis. Rondonópolis, MT, Brasil

Corresponding author: Letícia Silveira Goulart. E-mail: Igoulart77@yahoo.com.br.

Submitted on $07 / 31 / 2018$.

Accepted on 12/27/2018.

DOI: 10.1590/2177-9465-EAN-2018-0228

\section{Abstract}

Objective: The aim of the present study was to determine the prevalence and factors associated with the medication consumption among users registered in the Family Health Strategy (FHS) of Rondonópolis, Mato Grosso State, Brazil. Method: The population was constituted of all adult residents in the area covered by the FHS. The Poisson regression model with robust variance was used to the statistical analysis. Results: There were included 553 participants, of which $72 \%$ were women. The mean age was 48 years. The prevalence of medication consumption was about $74.9 \%(n=414)$. The most consumed class medication was drugs that act on the cardiovascular system (42.2\%). The factors associated with medication consumption were female gender ( $P R=1.21 ; C 195 \%: 1.07-1.38$ ), diagnosed morbidity ( $P R=1.83 ; C 195 \%: 1.61-2.08$ ) and be bedridden in the last month ( $P R=1.14$ 95\% Cl95\%: $1.02-1.26$ ). Moreover, $72.7 \%$ of the interviewees obtained the medicines in public pharmacies. Conclusion and implications for practice: Women, people diagnosed with morbidities and those participants who were bedridden during the last month showed the highest levels of drug consumption. Nursing professionals in promoting the rational use of medications can contribute to integral care to FHS users.

Keywords: Drug; prevalence; risk factors; Family Health Strategy; primary health care.

\section{Resumo}

Objetivo: $O$ objetivo deste estudo foi determinar a prevalência e os fatores associados ao consumo de medicamentos em usuários cadastrados em uma Estratégia de Saúde da Família (ESF) de Rondonópolis, Mato Grosso, Brasil. Método: A população foi constituída por todos os moradores adultos da área de abrangência da ESF. Para análise estatística foi empregado o modelo de regressão de Poisson com variância robusta. Resultados: Foram incluídos 553 participantes, dos quais $72 \%$ foram mulheres. A idade média foi de 48 anos. A prevalência do consumo de medicamentos foi de $74,9 \%(n=414)$. A classe medicamentosa mais consumida foi dos fármacos que atuam no aparelho cardiovascular ( $42,2 \%)$. Os fatores associados ao consumo de medicamentos foram sexo feminino ( $R P=1,21 ;$ IC95\%: 1,07 - 1,38), morbidade diagnosticada ( $R P=1,83 ;$ IC95\%: 1,61 - 2,08) e estar acamado no último mês ( $R P=1,14 ;$ IC95\%: 1,02 - 1,26). Uma frequência de $72,7 \%$ dos entrevistados obtém os medicamentos em farmácias públicas. Conclusão e implicações para a prática: Mulheres, indivíduos com diagnóstico de morbidade e participantes que estiveram acamados no último mês apresentaram maiores prevalências de consumo de medicamentos. Os profissionais de enfermagem ao promoverem o uso racional de medicamentos podem contribuir para um cuidado integral aos usuários da ESF.

Palavras-chave: Medicamento; fatores de risco; estratégia de saúde da família; atenção primária à saúde.

\section{REsumen}

Objetivo: El objetivo de este estudio fue determinar la prevalencia y los factores asociados al consumo de medicamentos en los usuarios registrados en una Estrategia de Salud de la Familia (ESF) de Rondonópolis, del estado de Mato Grosso (Brasil). Método: El público fue formado por todos los adultos residentes en la zona de alcance de la ESF. Para el análisis estadístico fue utilizado el modelo de regresión Poison con varianza robusta. Resultados: Se incluyeron 553 participantes, de los cuales el $72 \%$ fueron mujeres. El promedio de edad fue de 48 años. La prevalencia de consumo de medicamentos fue de $74,9 \%(n=414)$. La clase de medicación más consumida fue la de los fármacos que actúan en el sistema cardiovascular (42.2\%). Los factores asociados al consumo de medicamentos fueron: género femenino ( $R P=1,21$; IC95\%: 1,07-1,38), morbilidad diagnósticada $(R P=1,83 ;$ IC95\%: 1,61-2,08) y estar encamado en el último mes (RP = 1,14; IC95\%: 1,02-1,26). Además, 72,7\% de los entrevistados obtiene los medicamentos en farmacias comerciales. Conclusión e implicaciones para la práctica: Mujeres, personas diagnosticadas con morbilidad y participantes que estaban encamados en el último mes, presentaron mayor prevalencia de consumo de medicamentos. Los profesionales de enfermería al promover el uso racional de medicamentos pueden contribuir para un cuidado integral a los usuarios de la ESF.

Palabras clave: Medicamento; prevalencia; factores de riesgo; estrategia de Salud Familiar; atención primaria de salud. 


\section{INTRODUCTION}

The medications represent relevant health instruments, which aim to reduce the suffering and disrupting illness process, in addition to contributing to the improvement in the quality of life of individuals with chronic conditions. ${ }^{1}$ With the scientific and technological advances, obtained over the past decades, in the area of health, the use of medication has become essential in the treatment and prevention of diseases. ${ }^{2}$ At the same time, it is possible to consider the appropriate consumption of medications as highly cost-effective technology, since it can contribute significantly to the care and health care of the population. ${ }^{3}$

In the last years, it has seen increasing interest in the use of medication by the population, as well as the factors associated with this practice. This interest can be justified by the increasing use of drugs in the different social levels, by the expansion of public policies focused on the access to medications and the complexity of the pharmaceutical market. ${ }^{4}$ Epidemiological enquiries indicate that the medication consumption may be influenced by sex, age, income, self-health perception, diagnostic of chronic disease, affiliation to health insurance, number of medical consultations ${ }^{5,6}$.

Studies of medications use meet important purposes, such as: description of patterns of medications, assessment of educational measures effects, detection of inadequate use, estimate of a society's needs of medications, among others. ${ }^{7}$ The data generated by these researches can orient towards the integrality of the care and the actions of health promotion, especially at the primary health care ${ }^{8}$. The set of elements that characterize the pharmaceuticals consumption also enable the assessment and improvement of policies and programs aiming at promoting the rational use of medications. ${ }^{9}$

This rational use involves a set of actors that influences directly and indirectly the promotion of the adequate use of medications. The actors involved in this context are the State, the pharmaceutical market, the health professionals and the health care service user. ${ }^{10}$ In this context, the medication consumption should also be rethought in the attention to health. The fields of basic attention are health assistance scenarios, including the Family Health Strategy units (ESF), and should carry out the health promotion and diseases prevention. The multi and inter-disciplinary teams in the ESF must contribute to promote the rational use of medications. ${ }^{11}$ In this context, the present study searched to evaluate the prevalence and the factors associated with medications consumption by users of a ESF.

\section{METHODS}

This is a cross-sectional outpatient-based study carried out in the coverage area of a Family Health Strategy Unit (ESF) of the city of Rondonopolis, Mato Grosso, situated $215 \mathrm{Km}$ from the capital Cuiabá, to the south of the state. Rondonopolis, currently, has a population estimated in 22, 316 inhabitants. ${ }^{12}$

The population of this study constituted of all adult residents, aged 18 or older in the coverage area of the ESF Vila Cardoso.
This unit was chosen because it's where the project researchers actuate which are linked to the Health Multiprofessional Residence Program in Family Health of the Federal University of Mato Grosso, University Campus of Rondonopolis.

Data was collected during the period between July 2015 and April 2016, through home visits, being included all the residences of the coverage area of the unit. The residents who were not found in up to three attempts to contact them on different schedules and days of week were considered as losses. The researchers responsible for data collection have received training for carrying out the home visits. We conducted a pilot study with the purpose of testing the adequacy of the questionnaire and the procedures proposed. It was used as instrument a semi-structured form composed of 21 questions relating to the sociodemographic aspects, health conditions and medication consumption. The economic level was classified according to the Brazilian Criteria for Economic Classification, developed by the Research Companies Brazilian Association (ABEP). ${ }^{13}$

At the time of data collection, the participants informed which were the medications in use, being considered a reminder period of seven days. ${ }^{5}$ With the objective of avoiding oversight, omission or confounding, and consequently, ensure the veracity of the pharmaceutical products informed, the researched were requested to show the packaging, recipe, package leaflet or blister of the medications consumed ${ }^{14}$. The concomitant use of five or more medications in the last 7 days was considered polypharmacy. ${ }^{15}$

The present active principles in each specialty were listed and organized in accordance with the Anatomical Therapeutic Chemical classification (ATC) ${ }^{16}$, developed by the Nordic Council on Medicines and recommended by the Drug Utilization Research Group (DURG) of the World Health Organization (OMS) for use of medications studies. Medications that had more than an active principle were listed on the therapeutic class of the main component; medications with different pharmacological actions were classified according to its therapeutic indication. ${ }^{5}$

All participants signed the informed signed the informed consent form, and were informed about the objectives, risks, benefits and of the confidentiality of the collected data. The project was approved by the Ethics Research Committee of the Julio Muller Hospital under protocol number 1,113,303.

The dependent variable of this study was the medication consumption. The independent variables were sex, age, schooling variables were sex, age, education, situation in the labor market, socioeconomic level, health self-perception, bedridden in the last month, consultation with a doctor on the last three months, hospitalization in the last twelve months and diagnosed disease. The information was double-typed in the databases, which after validation generated the final databases. For study of associations, we employed gross adjusted ratios, using the simple and multiple Poisson regression with robust variance, respectively. All variables that presented $p<0.20$ were included in the multiple regression model, adjusted by the confounding variables such as age group and sex. The statistical significance 
of prevalence ratios obtained in the Poisson regression models was evaluated by the Wald test. We used the Stata version 12.0 (Stata Corp LP, College Station, USA) to analyze the data.

\section{RESULTS}

Five hundred fifty-three individuals participated in the study, of which $72.7 \%$ were female and the age group varied from 18 to 92 years, with an average age of 48 years. Regarding the level of education, $55.9 \%$ studied up to complete primary school. The users who said that they did not work, retirees and pensioners formed a group corresponding to a $60.2 \%$ of those interviewed. Most $(70 \%)$ participants of the study were classified as B and C stratum for ABEP classification. Table 1 shows the socio-demographic, health and use of the health services characteristics of the population under study.

Table 1. Socio-demographic, health and use of the health services characteristics of the users registered in an ESF. Rondonópolis, MT. (2016)

\begin{tabular}{|c|c|c|}
\hline Variables & $\mathrm{n}$ & $\%$ \\
\hline \multicolumn{3}{|l|}{ Sex } \\
\hline Male & 151 & 273 \\
\hline Female & 402 & 72.7 \\
\hline \multicolumn{3}{|l|}{ Age in years } \\
\hline $18-59$ & 403 & 72.9 \\
\hline$\geq 60$ & 150 & 27.1 \\
\hline \multicolumn{3}{|l|}{ Schooling } \\
\hline $\begin{array}{l}\text { Illiterate/Incomplete or complete } \\
\text { primary school }\end{array}$ & 309 & 55.9 \\
\hline $\begin{array}{l}\text { Incomplete or complete high school } \\
\text { level /higher }\end{array}$ & 244 & 44.1 \\
\hline \multicolumn{3}{|l|}{ Work situation } \\
\hline Retiree/pensioner/does not work & 333 & 60.2 \\
\hline It Works & 220 & 39.8 \\
\hline \multicolumn{3}{|l|}{ Economic Level* } \\
\hline Classes A and B & 166 & 30.0 \\
\hline Classes C and D & 387 & 70.0 \\
\hline \multicolumn{3}{|l|}{ Self-perception of health } \\
\hline Very good/good & 319 & 57.7 \\
\hline Regular/bad & 234 & 42.3 \\
\hline \multicolumn{3}{|l|}{ Bedridden during the last month } \\
\hline Yes & 56 & 10.1 \\
\hline No & 497 & 89.9 \\
\hline \multicolumn{3}{|l|}{ Consultation in the last 3 months } \\
\hline Yes & 337 & 60.9 \\
\hline No & 216 & 39.1 \\
\hline
\end{tabular}

\begin{tabular}{lcc}
\hline Variables & $\mathrm{n}$ & $\%$ \\
\hline $\begin{array}{l}\text { Hospitalization in the last year } \\
\text { Yes }\end{array}$ & 76 & 18.7 \\
No & 477 & 86.3 \\
Morbidity diagnosed & \\
Yes & 284 & 51.4 \\
No & 269 & 48.6 \\
* * Classification according the Research Companies Brazilian Association (ABEP)
\end{tabular}

As can be seen in Table 1, 57.7\% of residents in the coverage area of the ESF have considered that its proper general state of health was good or very good; $89.9 \%$ were not bedridden in the last 30 days prior to the research; $86.3 \%$ denied hospitalization in the last year; $60.9 \%$ informed medical consultation in the last 3 months and $51.4 \%$ stated that they had any diagnosed disease.

The prevalence of medications consumption was $74.9 \%$, and 940 were identified. Polipharmacy was verified in (10.7\%) users.

In the bivariate analysis it evidenced association of some socio-demographic and health condition with the use of medications (Table 2). According to the results, elderly women ( $(\geq 60$ years) , individuals with low schooling (illiterate/incomplete or complete primary school), economically inactive (retiree/ pensioner/does not work) presented the highest prevalence of consumption, self-reported that presented morbidity diagnosis, have good, regular/bad health, who were recently bedridden and under medical consultation $(p<0.05)$.

Table 2. Gross prevalence ratio of medications consumption, concerning socio-demographic aspects, indicators of health conditions and access to health services of users registered in an ESF. Rondonópolis, MT. (2016)

\begin{tabular}{lccc}
\hline Variable & $\begin{array}{c}\text { Gross } \\
\text { PR }\end{array}$ & Cl95\% & p Value \\
\hline Sex & & & \\
Male & 1.00 & $1.10-1.46$ & 0.001 \\
Female & 1.27 & &
\end{tabular}

\section{Age in years}

$\begin{array}{llll}18-59 \text { years } & 1.00 & 1.19-1.43<0.001 \\ \geq 60 \text { years } & 1.30 & & \end{array}$

\section{Schooling}

Illiterate/complete $\begin{array}{llll}\text { or incomplete primary } \quad & 1.00 & 0.76-0.95 & 0.004\end{array}$ school

Complete or incomplete high school level / $\quad 0.85$ higher

\section{Work Situation}

Retiree/pensioner/ does not work 


\begin{tabular}{lccc}
\hline Variable & $\begin{array}{c}\text { Gross } \\
\text { PR }\end{array}$ & Cl95\% & p Value \\
\hline
\end{tabular}

\begin{tabular}{llll}
\hline It Works & 0.85 & & \\
Economic Level & & & \\
Classes A and B & 1.00 & $0.94-1.17$ & 0.409 \\
Classes C and D & 1.05 & &
\end{tabular}

\section{Self-perception of he-}

alth

\begin{tabular}{|c|c|c|c|}
\hline Very good/good & 1.00 & & \\
\hline Regular/bad & 1.21 & $1.09-134$ & $<0.001$ \\
\hline \multicolumn{4}{|c|}{$\begin{array}{l}\text { Bedridden in the last } \\
\text { month }\end{array}$} \\
\hline Yes & 1.25 & $1.11-1.40$ & $<0.001$ \\
\hline No & 1.00 & & \\
\hline \multicolumn{4}{|c|}{$\begin{array}{l}\text { Consultation in the last } \\
3 \text { months }\end{array}$} \\
\hline Yes & 1.09 & $0.96-1.25$ & 0.195 \\
\hline No & 1.00 & & \\
\hline \multicolumn{4}{|c|}{$\begin{array}{l}\text { Hospitalization in the } \\
\text { last year }\end{array}$} \\
\hline Yes & 1.26 & $1.12-1.42$ & $<0.001$ \\
\hline No & 1.00 & & \\
\hline \multicolumn{4}{|c|}{ Morbidity diagnosed } \\
\hline Yes> & 1.88 & $1.67-2.14$ & $<0.001$ \\
\hline No & 1.00 & & \\
\hline
\end{tabular}

After control of confusion factors through logistic regression, the variables that remained significantly associated were sex, diagnosed disease and bedridden in the last month (Table 3). Women (PR: 1.21, Cl 95\%: 1.07 - 1.38), individuals with diagnosed morbidity (PR: 1.83, IC 95\%: $1.61-2.08$ ) and participants who were bedridden in the last month (RP: 1.14, IC 95\%: 1.02 - 1.26) presented higher prevalence of medications use.

The medications that act in the cardiovascular system (42.2\%), nervous system (19.9\%) and skeletal muscle system $(13 \%)$ were the most consumed. Pharmaceuticals that act on the renin-angiotensin system, diuretic, anti-inflammatory and anti-rheumatic were the most used therapeutic sub-classes (Table 4).

The participants were asked about which professionals they sought in case of doubts regarding the use of medications, the most indicated the doctor (44.3\%) and the pharmacist (36.5\%). On the purchase or obtaining the medications, $72.7 \%$ informed they make use of public pharmacies.

\section{DISCUSSION}

Population-based epidemiological studies can provide a true profile picture of medications use, and are useful to guide local
Table 3. Poisson multiple regression model for medications consumption of users registered in an ESF. Rondonópolis, MT. (2016)

\begin{tabular}{|c|c|c|c|}
\hline Variable & $\begin{array}{c}\text { Ad- } \\
\text { justed } \\
\text { PR* }^{*}\end{array}$ & $\mathrm{Cl} 95 \%$ & $p$ Value \\
\hline \multicolumn{4}{|l|}{ Sex } \\
\hline Male & 1.00 & & \\
\hline Female & 1.21 & $1.07-1.38$ & 0.002 \\
\hline \multicolumn{4}{|l|}{ Age group } \\
\hline $18-59$ years & 1.00 & & \\
\hline 60 years & 1.04 & 0.96 - 1.12; & 0.372 \\
\hline \multicolumn{4}{|c|}{ Diagnosed morbidity } \\
\hline Yes & 1.83 & $1.1-2.08$ & \\
\hline No & 1.00 & & $<0.001$ \\
\hline \multicolumn{4}{|c|}{$\begin{array}{l}\text { Bedridden in the last } \\
\text { month }\end{array}$} \\
\hline Yes & 1.14 & $1.02-1.26$ & 0.015 \\
\hline No & 1.00 & & \\
\hline
\end{tabular}

Table 4. Distribution of medications used in the last seven days, according to the ATC classification, of users from a Family Health Strategy. Rondonópolis, MT. (2016)

\begin{tabular}{|c|c|c|c|}
\hline Therapeutic class & $\mathrm{n}$ & Total & $\%$ \\
\hline $\begin{array}{l}\text { A - Digestive tract and me- } \\
\text { tabolism }\end{array}$ & & 115 & 12.2 \\
\hline $\begin{array}{l}\text { A10 - Medications used in } \\
\text { diabetes }\end{array}$ & 56 & & \\
\hline $\begin{array}{l}\text { A02 - Antacids, medications } \\
\text { for the treatment of peptic } \\
\text { ulcer and flatulence }\end{array}$ & 23 & & \\
\hline A11 - Vitamins & & & \\
\hline Others & & & \\
\hline $\begin{array}{l}\text { B - Blood and blood-forming } \\
\text { organs }\end{array}$ & & 20 & 21 \\
\hline $\begin{array}{l}\text { B03 - Anti-anemic prepara- } \\
\text { tions }\end{array}$ & 10 & & \\
\hline $\begin{array}{l}\text { B01 - Antithrombotic medi- } \\
\text { cations }\end{array}$ & 6 & & \\
\hline Others & 4 & & \\
\hline C-Cardiovascular system & & 397 & 42.2 \\
\hline $\begin{array}{l}\text { C09 - Renin-angiotensin- } \\
\text {-system-acting agents }\end{array}$ & 130 & & \\
\hline C03-Diuretic & 105 & & \\
\hline CO2 - Anti-hipertensives & 55 & & \\
\hline
\end{tabular}




\begin{tabular}{|c|c|c|c|}
\hline Therapeutic class & $\mathrm{n}$ & Total & $\%$ \\
\hline $\begin{array}{l}\text { C10 - Lipid-lowering medi- } \\
\text { cation }\end{array}$ & 25 & & \\
\hline Others & 82 & & \\
\hline $\begin{array}{l}\text { G-Genitourinary system and } \\
\text { sexual hormones }\end{array}$ & & 24 & 2.5 \\
\hline $\begin{array}{l}\text { G03 - Sexual hormones and } \\
\text { modulators of the genital } \\
\text { system }\end{array}$ & 24 & & \\
\hline $\begin{array}{l}\mathrm{H} \text {-Systemic hormonal pre- } \\
\text { parations, excluding sexual } \\
\text { hormones }\end{array}$ & & 20 & 2.1 \\
\hline HO3 - Thyroid therapeutic & 17 & & \\
\hline Others & 4 & & \\
\hline $\begin{array}{l}\text { J-General anti-infective for } \\
\text { systemic use }\end{array}$ & & 21 & 2.2 \\
\hline $\begin{array}{l}\text { J03 - Antibacterial drugs for } \\
\text { systemic use }\end{array}$ & 17 & & \\
\hline Others & 4 & & \\
\hline sM - Skeletal muscle system & & 122 & 13.0 \\
\hline $\begin{array}{l}\text { M01 - anti-inflammatory } \\
\text { and antirheumatic }\end{array}$ & 109 & & \\
\hline Others & 13 & & \\
\hline $\mathrm{N}-$ Nervous system & & 187 & 19.9 \\
\hline N02 - Analgesics & 82 & & \\
\hline N05 - Psycholeptics & 43 & & \\
\hline N06 - Psychoanaleptics & 24 & & \\
\hline Others & 38 & & \\
\hline Others & & 34 & 3,6 \\
\hline $\begin{array}{l}\text { D - Dermatologic medica- } \\
\text { tions }\end{array}$ & 11 & & \\
\hline $\begin{array}{l}\mathrm{L}-\text { Antineoplastic and immu- } \\
\text { nomodulators }\end{array}$ & 4 & & \\
\hline $\mathrm{R}$ - Respiratory system & 14 & & \\
\hline S - Sensitive organs & 5 & & \\
\hline TOTAL & & 940 & 100 \\
\hline
\end{tabular}

actions public policies and also new researches in this area. ${ }^{2}$ The frequency of medications consumption in the population studies was $74.9 \%$, result similar to that observed in Florianopolis, SC $(76.5 \%)^{10}$, however, these values are higher than the national data that point to a prevalence of $50.7 \%$ in the Brazilian population and $51.8 \%$ in the center-west region ${ }^{17}$. The use of medications observed in this study was also superior to the researches carried out in Fortaleza, CE $(49.7 \% 2)^{6}$, Pelotas, RS $(65.9 \%)^{18}$ and in Ponta Grossa, PR $(67.1 \%)^{5}$.
It is important to highlight some limitations of this research, as the fact that users of the coverage area from a single ESF to be included, then, a future population-based study should be conducted. I was analyzed the consumption of medications during the last 7 days, however, despite this procedure happenening quite often in epidemiological studies, the comparations with other researches should always take into consideration that the data can differ according to the reminder period of use. ${ }^{2}$ Added to these factors, it should take into consideration that in cross-sectional studies, the capture of information about all the variables is simultaneous, and its most limitation is the absence of guarantees about the time relation between the expositions and the outcomes. Such limitation is, in part compensated by the estimates in the successive studies, which strengthens the validity of the results. ${ }^{19}$

In this study, association was observed between medication consumption and female sex, corroborating with other national epidemiological investigations. ${ }^{17,20-22}$ Several factors make the women more likely to use medications, among them, the exclusive contraceptive use, her greater concern for health, the healthcare for the members of her family and a greater demand for health services..$^{20}$ The specific programs focused on woman health as the prenatal, breast and cervical cancer prevention contribute to health services provide more assistance to this portion of the population. ${ }^{4}$

The ESF elderly patients in study were found to present the highest prevalence of medication use. Population studies conducted in Brazil show that the advanced age is one of the main factors associated with the medications use. ${ }^{6,17,21,22}$ With the growing aging population and the success in the drugs access policy, there is a trend toward increasing the medications use by older people, indicating that this subject should be a priority on the Public Health System agenda (SUS ${ }^{23}$. The medications use among the older people constitutes an important therapeutic strategy, in order to compensate changes related to the aging process or control the most common chronic diseases in the third age, thus, the pharmacotherapeutic follow-up in older people is essential for promoting rational medications use ${ }^{24}$.

In this study it was identified that individuals with lower schooling and economically inactive (retiree/pensioner/ does not work) consumed more medications. Costa et al. observed greater use of medications among fewer educated individuals, when compared to those with higher schooling level 22 . In general, a higher schooling level is associated with a greater knowledge and discernment about the health-disease process ${ }^{6}$. Galvão et al. reported that the medications consumption was significantly greater in unemployed and retiree in Brasília, $\mathrm{DF}^{21}$. Francisco et al. described higher prevalence of medications use among unemployed men, however, this association was not observed in women ${ }^{20}$.

The medications consumption in the study population was also associated with presence of morbidity and being bedridden during the last month, an expected result, since the medications constitute important tools for health, which aim to minimize, in- 
terrupt the process of illness and improve the individuals' quality of life with chronic conditions ${ }^{1}$. Similar result was described in a population-based study carried out in the city of Campinas, SP, in which, in the final statistical analysis, after the adjustment for age and sex, the variables morbidity in the last 15 days and number of chronic diseases remained associated with the medications use. According to the authors, persons in these health conditions often search for the services and the medication is one of the therapeutic interventions used ${ }^{4}$.

The medications that act on the cardiovascular and nervous system were the most consumed by the users researched. Similar results are described in the literature ${ }^{4,5,17}$. Bertoldi et al. evaluated the generic medications consumption in Brazil, through the National Survey on Access, Use and Promotion of Rational Use of Medicines (PNAUM) data and identified that the medicines for the cardiovascular system (35.9\%), for the nervous system $(18.6 \%)$ and for the alimentary tract and metabolism (16.0\%) were the most used. ${ }^{25}$ Regarding the therapeutic sub-groups, the highest prevalence of generic medicines occurred for the agents that act on the renin-angiotensin system, corroborating with our study. ${ }^{25}$

The studied population indicated the doctor $(44.31 \mathrm{~m} \%)$ and the pharmacist (36.46\%) as the main responsible professionals for providing orientations on the use of medications. In Ponta Grossa, PR, the doctor was the main advisor on the use of drugs $(76.2 \%) .{ }^{5}$ In the city of Santa Rosa, RS, the doctor $(55.94 \%)$, the nurse $(16.40 \%)$ and the nursing technicians $(14.14 \%)$ were the professionals who provided the greatest contribution with pharmacological orientations. ${ }^{26}$ In Medelin, Colombia, the sources of information about the most used medications were the doctor $(73 \%)$, the internet $(44 \%)$ and the pharmacist $(43 \%) .{ }^{27}$ The population must be oriented on how to proceed with the use of medications, in order to guarantee a safe action and with lower risks to health. ${ }^{27}$ It is essential that the ESF team be able to guide users about the rational use of medications, aiming at the adhesion to the drug therapy, reduction of adverse effects, self-medication and drug interactions. It should be emphasized that the professional nurse should perform not only the orientation about the medications use, but also the prescription. In this context, therapeutic protocols should be developed, in order to help the category perform prescription actions on daily primary health care services. ${ }^{28}$

The achievement of medications in public pharmacies was observed in $72.7 \%$ of the studied population. In the study of Vosgerau et al., with adults of the coverage area of a ESF, the commercial pharmacy $(63,6 \%)$ was the main local of access to medications. ${ }^{5}$ Bertoldi et al., evaluated the use and access of medications in a population covered by the ESF and identified that $51 \%$ of medications were made available by the SUS. ${ }^{29}$ In the study of Costa et al., $30 \%$ of interviewees obtained all the medications who needed by means of public pharmacies, indicating that the most part of the population had to bear the costs of medications. ${ }^{22}$ In Brazil, the classes with the greater consumption level (A/B) acquire the generic medications, primarily, in private pharmacies (46.3\%), while in classes $C$ and $D / E$ (lower consumption level), about $50,0 \%$ of generic medications are obtained in public pharmacies (SUS). ${ }^{25}$ Collectively, these data point to a need for enhancement actions of pharmaceutical assistance, enabling the population to have better access to pharmacies and SUS medications programs.

\section{CONCLUSION}

Women, individual with diagnosis morbidity and participants who were bedridden in the last month showed the greatest prevalence of medications consumption. The information generated by this research constitute indicators that can subsidize public health policies actions and pharmaceutical assistance in the municipality of Rondonopolis, MT. The high medications consumption observed in the studied population suggests a need to carry out a multidisciplinary approach focused on the promotion of the rational medications use. The nursing professionals, as essential part of the ESF should take integral care for the users, which includes the promotion of the rational medications use, contributing then, to an effective and safe pharmacological treatment.

\section{REFERENCES}

1. Pontes Junior DM, Pepe VLE, Osorio-De-Castro CGS, Massena EP, Portela MC, Miranda MC, et al. A definição de medicamentos prioritários para o monitoramento da qualidade laboratorial no Brasil: articulação entre a vigilância sanitária e a Política Nacional de Medicamentos. Cad Saúde Pública [Internet]. 2008;24(9):2081-90. Available from: http:// www.scielo.br/scielo.php?script=sci_abstract\&pid=S0102-311X200 $8000900014 \&$ Ing=en\&nrm=iso\&tlng=pt

2. Bermudez JAZ, Barros MBA. Perfil do acesso e da utilização de medicamentos da população brasileira - contribuições e desafios da PNAUM - Inquérito Domiciliar. Rev Saúde Pública [Internet]. 2016;50(Suppl 2):1s-4s. Available from: http://www.rsp.fsp.usp. br/artigo/perfil-do-acesso-e-da-utilizacao-de-medicamentos-dapopulacao-brasileira-contribuicoes-e-desafios-da-pnaum-inqueritodomiciliar/

3. LeiteSN, VieiraM, Veber AP.Estudos de utilização de medicamentos:uma síntese de artigos publicados no Brasil e América Latina. Ciênc Saúde Coletiva [Internet].2008;13(Suppl):793-802. Available from: http://www. scielo.br/scielo.php?pid=S1413-81232008000700029\&script=sci_ abstract\&tIng=pt

4. Costa KS, Barros MBA, Francisco PMSB, César CLG, Goldbaum M, Carandina $L$, et al. Utilização de medicamentos e fatores associados um estudo de base populacional no Município de Campinas, São Paulo, Brasil. Cad Saúde Pública [Internet].2011 Apr;27(4):649-58. Available from: http://www.scielo.br/scielo.php?script=sci_arttext\&pid=S0102311X2011000400004

5. Vosgerau MZS, Soares DA, Souza RKT, Matsuo T, Carvalho GS. Consumo de medicamentos entre adultos na área de abrangência de uma Unidade de Saúde da Família. Ciênc Saúde Coletiva [Internet] 2011;16(Suppl.1):1629-38. Available from: http://www.scielo.br/scielo. php?script=sci_arttext\&pid=S1413-81232011000700099

6. Arrais PSD, Brito LL, Barreto ML, Coelho HLL. Prevalência e fatores determinantes do consumo de medicamentos no Município de Fortaleza, Ceará, Brasil. Cad Saúde Pública [Internet]. 2005;21(6):1737-46. Available from: http://www.scielo.br/scielo. php?pid=S0102-311X2005000600021\&script=sci_abstract\&tlng=pt 
7. Melo DO, Ribeiro E, Storpirtis S. A importância e a história dos estudos de utilização de medicamentos. Rev Bras Ciênc Farm. 2006 Oct/ Dec;42(4):475-85. Available from: http://bvsms.saude.gov.br/bvs/ is_digital/is_0207/pdfs/IS27(2)041.pdf

8. Ascef BO, Haddad JPA, Álvares J, Guerra Junior AA, Costa EA, Acurcio $F A$, et al. Qualidade de vida relacionada à saúde dos usuários da atenção primária no Brasil. Rev Saúde Publica [Internet]. 2017;51(Supl):2-22s. Available from: http://www.scielo.br/pdf/rsp/v51s2/ pt_0034-8910-rsp-S1518-51-s2-87872017051007134.pdf

9. Milian AJG, Verde LL, Barros MCP, Cabrera PL. Consumo de medicamentos y condiciones de vida. Rev Cubana Salud Pública. 2016;42(3):442-50. Available from: https://www.scielosp.org/article/ $\mathrm{ssm} /$ content/raw/?resource_ssm_path=/media/assets/rcsp/v42n3/ spu11316.pdf

10. Boing AC, Fernandes SC, Farias MR. Uso Racional de Medicamentos no âmbito da Estratégia da Saúde da Família: qual o entendimento e prática dos profissionais de saúde? Saude Transf Soc [Internet] 2012;3(3):84-8. Available from: http://incubadora.periodicos.ufsc.br/ index.php/saudeetransformacao/article/view/1594

11. Ministério da Saúde (BR). Portaria № 648, de 28 de março de 2006. Aprova a Política Nacional de Atenção Básica, estabelecendo a revisão de diretrizes e normas para organização da atenção básica para o Programa Saúde da Família (PSF) e o Programa de Agentes Comunitários de Saúde (PACS) [Internet]. Brasília (DF): Ministério da Saúde;2006 [cited 2017 Oct 25]. Available from: http://189.28.128.100/ dab/docs/legislacao/portaria_648_28_03_2006.pdf

12. Ministério do Planejamento, Orçamento e Gestão (BR). Instituto Brasileiro de Geografia e Estatística (IBGE). Censo Demográfico de 2010 [Internet]. Rio de Janeiro: IBGE; 2011 [cited 2017 May 13] Available from: $h$ ttps://biblioteca.ibge.gov.br/visualizacao/periodicos/93/ cd_2010_caracteristicas_populacao_domicilios.pdf

13. Associação Brasileira de Empresas e Pesquisa [Internet]. Critério de classificação econômica Brasil 2015. [cited 2017 May 2016]. Available from: http://www.abep.org/criterio-brasil

14. Landry JA, Smyer MA, Tubman JG, Lago DJ, Roberts J, Simonson W. Validation of two methods of data collection of self-reported medicine among the elderly. Gerontologist [Internet]. 1988 Oct;28(5):672-6. Available from: https://www.ncbi.nlm.nih.gov/pubmed/3229653

15. Gorard DA. Escalating polypharmacy. QJM [Internet]. 2006 Nov;99(11):797-800. Available from: https://www.ncbi.nlm.nih.gov/ pubmed/17030528

16. World Health Organization (WHO). Collaborating Centre for Drug Statistics Methodology. Guidelines for ATC classification and DDD assignment. 3rd ed. Oslo: World Health Organization; 2000.

17. Bertoldi AD, Dal Pizzo TS, Ramos LR, Mengue SS, Luiza VL, Tavares NUL, et al. Perfil sociodemográfico dos usuários de medicamentos no Brasil: resultados da PNAUM 2014. Rev Saúde Pública [Internet]. 2016;50(Suppl 2):1s-11s. Available from: https://www.lume.ufrgs.br/ bitstream/handle/10183/151192/001009560.pdf?sequence $=1$

18. Bertoldi AD, Barros AJD, Hallal PC, Lima RC. Utilização de medicamentos em adultos: prevalência e determinantes individuais Rev Saúde Pública [Internet].2004;38(2):228-38. Available from: http:// www.scielo.br/pdf/rsp/v38n2/19783.pdf
19. Rozenfeld S, Valente J. Estudos de utilização de medicamentos considerações técnicas sobre coleta e análise de dados. Epidemiol Serv Saúde [Internet]. 2004 Jun;13(2):115-23. Available from: http://scielo.iec. gov.br/scielo.php?script=sci_arttext\&pid=S1679-49742004000200005

20. Francisco PMSB, Bastos TF, Costa KS, Prado MAMB, Barros MBA. Uso de medicamentos e fatores associados em adultos residentes em Campinas, São Paulo, Brasil: diferenças entre homens e mulheres. Ciênc Saúde Coletiva [Internet]. 2011;19(12):4909-21. Available from: http://www.scielo.br/pdf/csc/v19n12/1413-8123-csc-19-12-04909.pdf

21. Galvao TF, Silva MT, Gross R, Pereira MG. Medication use in adults living in Brasilia, Brazil: a cross-sectional, population-based study. Pharmacoepidemiol Drug Saf [Internet]. 2014 May;23(5):507-14 Available from: https://www.ncbi.nlm.nih.gov/pubmed/24520028

22. Costa KS, Francisco PMSB, Barros MBA. Utilização e fontes de obtenção de medicamentos: um estudo de base populacional no Município de Campinas, São Paulo, Brasil. Cad Saúde Pública [Internet]. 2016;32(1):e00067814. Available from: http://www.scielo.br/scielo. php?pid=S0102-311X2016000100702\&script=sci_abstract\&tlng=pt

23. Ramos LR, Tavares NUL, Bertoldi AD, Farias MR, Oliveira MA, Luiza VL, et al. Polifarmácia e polimorbidade em idosos no Brasil: um desafio em saúde pública. Rev Saúde Pública [Internet]. 2016;50(Suppl 2):1s-9s. Available from: http://www.scielo.br/pdf/rsp/v50s2/pt_0034-8910-rsps2-S01518-87872016050006145.pdf

24. Goulart LS, Carvalho AC, Lima JC, Pedrosa JM, Lemos PL, Oliveira RB. Consumo de medicamentos por idosos de uma unidade básica de saúde de Rondonópolis/MT. Estud Interdiscipl Envelhec [Internet] 2014;19(1):79-94. Available from: https://seer.ufrgs.br/RevEnvelhecer/ article/view/25854/31002

25. Bertoldi AD, Arrais PSD, Tavares NUL, Ramos LR, Luiza VL, Mengue SS, et al. Utilização de medicamentos genéricos na população brasileira: uma avaliação da PNAUM 2014. Rev Saúde Pública [Internet]. 2016;50(Suppl 2):1s-11s. Available from: http://www.scielo.br/pdf/rsp/ v50s2/pt_0034-8910-rsp-s2-S01518-87872016050006120.pdf

26. Bandeira VAC, Oliveira KR, Asmann APG, Perassolo DD, Colet CF, Flores VB. Consumo de Medicamentos por Adultos Usuários de Três Unidades de Saúde da Família de Santa Rosa-RS: Perfi e Fatores Associados. Rev APS [Internet]. 2017 Jan/Mar;20(1):4758. Available from: http://ojs2.ufjf.emnuvens.com.br/aps/article/ view/15671/8206

27. Martínez-Domínguez GI, Martínez-Sánchez LM, Rodríguez-Gázquez MA. Characteristics of the consumption of non-prescription drugs in a population of adults in the city of Medellin (Colombia). Salud (Barranquilla) [Internet]. $2013 \mathrm{Sep} / \mathrm{Dec} ; 29(3): 360-7$. Available from: http://www.scielo.org.co/scielo.php?script=sci_arttext\&pid $=$ S0120-55522013000300002

28. Vasconcelos RB, Araújo JL. A prescrição de medicamentos pelos enfermeiros na estratégia saúde da família. Cogitare Enferm [Internet] 2013 Oct/Dec;18(4):743-50. Available from: https://revistas.ufpr.br/ cogitare/article/view/34931

29. Bertoldi AD, de Barros AJ, Wagner A, Ross-Degnan D, Hallal PC. Medicine access and utilization in a population covered by primary health care in Brazil. Health Policy [Internet]. 2009 Mar;89(3):295-302. Available from: https://www.ncbi.nlm.nih.gov/pubmed/18722031 